\title{
MANAJEMEN PENDIDIKAN MULTIKULTURAL PRESPEKTIF ULU AL-ALBAB
}

\author{
M. Fahim Tharaba \\ Program Studi Manajemen Pendidikan Islam, UIN Maulana Malik Ibrahim, \\ Malang, Jawa Timur, Indonesia \\ Email: fahimtarbiyah@yahoo.com
}

DOI: http://doi.org/10.33650/al-tanzim.v4i2.1076

\begin{tabular}{l|l|l} 
Received: March 2020 & Accepted: September 2020 & Published: September 2020 \\
\hline
\end{tabular}

\begin{abstract}
:
This study aims to describe form and practice of multicultural education management based on Ulu al-Albab perspective at State Islamic University (UIN) of Maulana Malik Ibrahim Malang. This study uses a qualitative approach with a bibliographic resarch type with content analysis on the meaning of multicultural education management based on Ulu al-Albab perspective. This study figures out that (1) several aspects were developed as a form of multicultural education, including aspects of institutional development, facilities and infrastructure, academic, research and community service, student affairs, quality assurance, cooperation, building a spirit of giving and sacrifice, and development of academic character and noble morals; (2) multicultural education, closely related to university programs, including implementation of integration of Islam and science, optimizing the role of ma'had, increasing foreign language competence, increasing the quantity of human resources, revitalization of social and religious roles, implementation of information technology-based management, internationalization of universities and international cooperation towards World Class University (WCU), implementation of institutional development, and exploration of funding sources.
\end{abstract}

Keywords: management, multicultural management, Ulu al-Albab

Abstrak:

Penelitian ini bertujuan untuk mendeskripsikan bentuk dan praktek pendidikan multikultural dalam manajemen prespektif Ulu al-Albab di Universitas Islam Negeri (UIN) Maulana Malik Ibrahim Malang. Penelitian ini menggunakan pendekatan kualitatif dengan jenis bibliografic resarch dengan content analysis terutama terhadap makna yang terkandung dalam keseluruhan pemikiran pendidikan multikultural dalam manajemen prespektif Ulu al-Albab. Hasil penelitian menunjukkan bahwa (1) beberapa aspek yang dikembangkan sebagai bentuk pendidikan multikultural, antara lain mencakup aspek pengembangan kelembagaan; sarana dan prasarana; akademik; penelitian dan pengabdian pada masyarakat; kemahasiswaan; jaminan mutu; kerjasama; membangun semangat memberi dan berkorban; dan pengembangan karakter akademik dan akhlak mulia; (2) pendidikan multikultural berkaitan erat dengan program universitas, meliputi: implementasi integrasi Islam dan sains, optimalisasi peran ma'had, peningkatan kompetensi bahasa asing, peningkatan kuantitas sumber daya manusia, revitalisasi peran sosial dan keagamaan, manajemen berbasis teknologi informasi, internasionalisasi universitas dan kerjasama internasional menuju World Class University (WCU), pengembangan kelembagaan, dan penggalian sumber pendanaan.

Kata Kunci: manajemen, pendidikan multikultural, Ulu al-Albab 


\section{PENDAHULUAN}

Pluralitas pada hakikatnya merupakan realitas kehidupan itu sendiri, yang tidak bisa dihindari dan ditolak. Karena pluralitas merupakan sunatullah, maka eksistensi atau keberadaanya harus diakui oleh setiap manusia, (Hidayatullah, 2016), namun pengakuan ini dalam tataran realitas belum sepenuhnya seiring dengan pengakuan secara teoritik dan kendala-kendala masih sering dijumpai di lapangan. Penelitian ini berangkat dari kenyataan bahwa dalam kehidupan sehari-hari sebelum dicampuri dengan kepentingan ideologis, ekonomis, sosial-politik, agamis dan lainnya, manusia menjalani kehidupan yang bersifat pluralitas secara alamiah, tanpa begitu banyak mempertimbangkan sampai pada tingkat 'benar-tidaknya' kenyataan pluralitas yang menyatu dalam kehidupan sehari-hari. Baru ketika manusia dengan berbagai kepentingannya baik di organisasi, politik, agama, budaya dan lainnya, mulai mengangkat isu pluralitas pada puncak kesadaran mereka dan menjadikannya sebagai pusat perhatian. Maka pluralitas yang semula bersifat wajar, alamiah berubah menjadi hal yang sangat penting (Ahmad, 2017).

Seiring dengan maraknya proses liberalisasi sosial politik yang menandai lahirnya tatanan dunia abad modern, dan disusul dengan liberalisasi atau globalisasi (penjajahan model baru) ekonomi, wilayah agama pun pada gilirannya dipaksa harus membukakan diri untuk diliberalisasikan. Agama yang semenjak era reformasi gereja abad ke-15 wilayah juridiksinya telah diredusir, dimarjinalkan dan didomestikasikan sedemikian rupa, yang hanya boleh beroperasi di sisi kehidupan manusia yang paling privat, ternyata masih diangap tidak cukup kondusif bagi terciptanya tatanan baru yang harmoni, demokratis dan menjunjung tinggi nilai-nilai kemanusiaan dan Hak Asasi Manusia (HAM), seperti toleransi, kebebasan, persamaan dan pluralisme. Seakan-akan semua agama secara general adalah musuh demokrasi, kemanusiaan dan HAM. Sehingga agama harus mendekonstruksikan diri atau didekonstruksikan secara paksa, agar menurut bahasa kaum liberal, merdeka dan bebas dari kungkungan teks-teks dan tradisi yang jumud serta tidak sesuai lagi semangat zaman (Suyatno, 2015).

Agama sebagai sebuah tatanan nilai sebenarnya membutuhkan medium budaya agar keberadaannya membumi dalam kehidupan umat pemeluknya dan ia diharapkan menjadi institusi bagi pengalaman iman kepada Sang Khaliq. Di sini agama menawarkan agenda penyelamatan manusia secara universal, namun di sisi yang lain agama sebagai sebuah kesadaran makna dan legitimasi tindakan bagi pemeluknya, dalam interaksi sosialnya banyak mengalami perbedaan hermeunetik sehingga tidak pelak memunculkan konflik. Pluralitas agama di satu sisi, dan heterogenitas realitas sosial pemeluknya di sisi yang lain, tidak jarang menimbulkan benturan-benturan dalam tataran tafsir atau dogma agama maupun dalam tataran aksi (Baharun \& Awwaliyah, 2017). Disadari atau tidak, konflik kemudian menjadi problem kebangsaan dan keagamaan yang tidak bisa hanya diselesaikan lewat pendekatan teologi normatif. Akan tetapi, diperlukan pendekatan lain, yaitu sikap kearifan sosial di antara kelompok kepentingan dan kalangan pemeluk paham atau agama. 
Mengintegrasikan budaya prestasi pada fungsi perencanaan kegiatan pembinaan mutu dosen di perguruan tinggi menjadi sebuah ikhtiar untuk mengawali perubahan di perguruan tinggi yang senantiasa meniscayakan perbaikan manajemen ke arah yang semakin efisien, efektif, dan produktif, begitu pula bagaimana mahasiswa dipersiapkan untuk itu, sehingga budaya prestasi yang dipadu dengan persiapan untuk hidup multikultur menjadi penting adanya (Riyanta, 2016). Hasil penelitian Rostiawati (2020) menunjukkan bahwa sangat penting untuk dilakukan pendidikan dan pelatihan dalam rangka peningkatan kualitas manajemen kepemimpinan, sehingga bagaimana mahasiswa dipersiakan, untuk itu penting untuk memenejnya dalam sebuah model manajemen pendidikan, terutama berkaitan dengan realitas multikultur.

Demikianlah, citra dan jati-diri "insan kamil harapan" yang diupayakan Universitas Islam Negeri (UIN) Maulana Malik Ibrahim Malang adalah insan Ulu al-Albab. Ulu al-Albab adalah sosok yang mempunyai ketajaman hati dan pandangan yang luas yang tercermin dari berkembangnya empat potensi Ulu al-Albab, yaitu potensi kedalaman spiritual, keagungan akhlak, keluasan ilmu dan kematangan profesional. Semua potensi tersebut akan berhasil dikembangkan dengan baik jika dilakukan dengan rencana yang tepat.

\section{METODE PENELITIAN}

Studi ini menggunakan pendekatan kualitatif dengan jenis bibliografic research (Nasution, 2014). Adapun analisis data yang digunakan sesuai dengan sifat penelitian bibliografic resarch adalah analisis isi (content analysis) terutama terhadap makna dan substansi yang terkandung dalam keseluruhan pemikiran pendidikan multikultural dalam manajemen prespektif Ulu al-Albab (Muhadjir, 1993). Makna Ulu al-Albab mencakup tiga pilar, yakni dzikir, fikir dan amal shaleh. Secara lebih detail, Ulu al-Albab adalah kemampuan seseorang dalam merenungkan secara mendalam fenomena alam dan sosial, yang hal itu mendorongnya mengembangkan ilmu pengetahuan, dengan berbasis pada kepasrahan secara total terhadap kebesaran Allah SWT, untuk dijadikan sebagai penopang dalam berbagai karya (Patton, 1980).

\section{HASIL DAN PEMBAHASAN}

\section{Pendidikan Multikultural Kajian Manajemen Prespektif Ulu al-Albab}

Islam memandang bahwa mahasiswa merupakan komunitas yang terhormat dan terpuji (Q.S. al-Mujadalah : 11), karena ia merupakan komunitas yang menjadi cikal bakal lahirnya ilmuan (scientist) yang diharapkan mampu mengembangkan ilmu pengetahuan dan memberikan penjelasan pada masyarakat dengan pengetahuannya itu (Q.S. al-Tawbah : 122). Oleh karenanya, mahasiswa dianggap sebagai komunitas yang penting untuk menggerakkan masyarakat Islam khususnya, dan seluruh umat manusia pada umumnya, menuju kekhalifahan yang mampu membaca alam nyata sebagai sebuah keniscayaan ilahiyah (Q.S. Ali Imran : 191), yakni mampu mengintegralkan diri dan melebur dalam kesadaran kemanusiaan dan ketuhanan dalam waktu yang bersamaan (Sidi, 2001) 
Untuk mencapai hal yang disebut terakhir, mahasiswa Islam dalam melakukan pembacaan alam nyata yang dikembangkan dalam fakultas ilmuilmu alam, seperti biologi, fisika, kimia, dan ilmu-ilmu sosial, seperti ilmu pendidikan, ilmu hukum, ilmu ekonomi, psikologi, ilmu bahasa, harus mempunyai dasar-dasar keilmuan ilahiyah yang didasarkan atas pemahaman terhadap wahyu secara baik (Kurniawan, 2013). Karena itu, agama pada dasarnya membawa misi sebagai pembawa kedamaian dan keselarasan dalam kehidupan sosial dengan mambawa nilai kebersamaan (ijtima'iyyah), keadilan (a'dalah), toleransi (tasamuh) permusyawaratan (syura), pembebasan (taharrur) sesuai dengan kondisi masyarakat yang pluralistik, sesuai visi Islam yang rahmatan lil'alamain (Fauzi, 2018), baik itu agama Islam sendiri dan agama lainnya. Namun, dalam kenyataannya tidak jarang agama bukannya menjadi pemersatu sosial, tetapi malah sebaliknya sebagai unsur konflik. Hal ini disebabkan dengan adanya truth claim pada tiap-tiap pemeluknya. Al-Qur'an sebagai wahyu Allah, dalam pandangan dan keyakinan umat Islam adalah sumber kebenaran dan mutlak itu tidak akan tampak manakala tidak dipahami.

Berbicara tentang masyarakat dan agama, tentu tidak bisa lepas dengan budaya, ideologi, dan politik. Karena itu, manusia pada hakikatnya dikatakan sebagai makhluk paling sempurna, ia memiliki naluri, kemampuan berfikir, akal, dan keterampilan, senantiasa memperjuangkan eksistensi, pertumbuhan dan kelangsungan hidup, berupaya memenuhi baik materi maupun spiritual. Oleh karena itu, manusia berbudaya akan selalu mengandung hubunganhubungan dengan agama, ideologi, politik, dan budaya (Sagala, 2008). Demikian untuk mempertahankan eksisitensinya dan kelangsungan hidupnya manusia perlu mengadakan hubungan, antara lain: pertama, hubungan manusia dengan Tuhan yang kemudian melahirkan agama; kedua, hubungan manusia dengan manusia yang kemudian melahirkan sosial; ketiga, hubungan manusia dengan cita-cita yang kemudian melahirkan ideology; keempat; hubungan manusia dengan kekuatan yang kemudian melahirkan politik; kelima; hubungan manusia dengan keindahan yang kemudian melahirkan budaya (Yusuf, 2014).

Demikian pula, fenomena dalam masyarakat tidak bisa lepas dari agama, ideologi, politik dan budaya yang saling berhubungan. Agama dan ideologi saling berhubungan, karena tanpa agama, masyarakat tidak akan tertata dengan baik. Agama dengan politik juga saling berhubungan, karena munculnya fenomena tentang agama khususnya theologi berawal dari politik pada masa kholifah Ali bin Abi Tholib. Dari segi budayapun juga berhubungan. Budaya yang ada di Indonesia ini tidak bisa dipisahkan dengan agama hal ini bisa kita lihat dari berbagai agama yang ada di Indonesia yang memiliki ciri khas tertentu.

Pada aspek yang lain, pluralitas pada hakikatnya merupakan realitas kehidupan itu sendiri, yang tidak bisa dihindari dan ditolak. Karena pluralitas merupakan sunatullah, maka eksistensi atau keberadaanya harus diakui oleh setiap manusia. Namun pengakuan ini dalam tataran realitas belum sepenuhnya seiring dengan pengakuan secara teoritik dan kendala-kendala masih sering dijumpai di lapangan (Fauzi, 2018). 
Dalam kehidupan sehari-hari sebelum dicampuri dengan kepentingan ideologis, ekonomis, sosial-politik, agamis dan lainnya, manusia menjalani kehidupan yang bersifat pluralitas secara ilmiah, tanpa banyak mempertimbangkan sampai pada tingkat "benar-tidaknya" realitas pluralitas yang menyatu dalam kehidupan sehari-hari. Baru ketika manusia dengan berbagai kepentingannya (organisasi, politik, agama, budaya dan lainnya) mulai mengangkat isu pluralitas pada puncak kesadaran mereka dan menjadikannya sebagai pusat perhatian. Maka, pluralitas yang semula bersifat wajar, alamiah berubah menjadi hal yang sangat penting (Saleh, 2004).

Seiring dengan maraknya proses liberalisasi sosial politik yang menandai lahirnya tatanan dunia abad modern, dan disusul dengan liberalisasi atau globalisasi (penjajahan model baru) ekonomi, wilayah agama pun pada gilirannya dipaksa harus membukakan diri untuk diliberalisasikan (Farikah, 2019). Agama, yang semenjak era reformasi gereja abad ke-15 wilayah juridiksinya telah diredusir, dimarjinalkan dan didomestikasikan sedemikian rupa, yang hanya boleh beroperasi di sisi kehidupan manusia yang paling privat, ternyata masih dianggap tidak cukup kondusif bahkan mengganggu bagi terciptanya tatanan dunia baru yang harmoni, demokratis dan menjunjung tinggi nilai-nilai kemanusiaan dan Hak Asasi Manusia (HAM), seperti toleransi, kebebasan, persamaan dan pluralism (Hidayati, 2016). Seakan-akan semua agama secara general adalah musuh demokrasi, kemanusiaan dan HAM (Setiawan, 2017). Agama harus mendekonstruksikan diri (atau didekonstruksikan secara paksa) agar, menurut bahasa kaum liberal, merdeka dan bebas dari kungkungan teks-teks dan tradisi yang jumud serta tidak sesuai lagi semangat zaman (Dakir \& Anwar, 2020)

Agama sebagai sebuah tatanan nilai sebenarnya membutuhkan medium budaya agar keberadaannya membumi dalam kehidupan umat pemeluknya dan ia diharapkan menjadi institusi bagi pengalaman iman kepada Sang Khaliq. Agama menawarkan agenda penyelamatan manusia secara universal, namun di sisi yang lain agama sebagai sebuah kesadaran makna dan legitimasi tindakan bagi pemeluknya, dalam interaksi sosialnya mengalami perbedaan hermeneutik, sehingga tidak pelak memunculkan konflik. Pluralitas agama di satu sisi, dan heterogenitas realitas sosial pemeluknya di sisi yang lain, tidak jarang menimbulkan benturan-benturan dalam tataran tafsir maupun dalam tataran aksi. Disadari atau tidak, konflik kemudian menjadi problem kebangsaan dan keagamaan yang tidak bisa hanya diselesaikan lewat pendekatan teologi normatif. Akan tetapi, diperlukan pendekatan lain, yaitu sikap kearifan sosial di antara kelompok kepentingan dan kalangan pemeluk paham atau agama, termasuk paham pluralisme agama dalam pendidikan mulikultural, baik persoalan teologi dan syari'ah ataupun sisi manajerialnya. Berkaiatan dengan pendidikan Ulu al-Albab, istilah Ulu al-Albab muncul 16 kali dalam kitab suci al-Quran, yaitu dalam al-Quran Surat al-Baqarah : 179, 197, 269; Ali Imrān : 7, 190; al-Māidah : 100; Yusuf : 111; al-Ra'dengan : 19, Ibrahim : 52; Shād : 29, 43; al-Zumar : 9, 18, 21; al-Mu'min : 54, dan al-Thalaq : 10 (Maskawaih, 1976) 
Dalam perspektif al-Quran, kata Ulu al-Albab yang dimaknai sebagai orang-orang yang berakal sebenarnya tidak terlalu tepat. Terjemahan Inggris men of understanding men of wisdom, mungkin lebih tepat. Kata Ulu al-Albab terdiri dari dua suku kata, yaitu kata ulū dalam kamus bahasa Arab berarti 'yang mempunyai' atau 'yang memiliki.' Kata albāb merupakan bentuk jamak dari $l u b b$, sebuah kata benda yang berarti 'intisari, isi atau bagian penting dari sesuatu.' Al-bāb juga berarti akal, cerdik, hati. Pada konteks tersebut, kata tersebut memperlihatkan visi pemikiran dan ilmu pengetahuan, sebuah akal yang memberi manfaat kepada pemiliknya dengan memilah isi substansi dari kulitnya. Seruan ya uli al-albāb berarti 'akal-akal yang bersih,' ' pemahaman yang cemerlang,' yang terlepas dari semua ikatan fisik, sehingga ia mampu menangkap ketinggian taqwa dan menjaga ketaqwaan itu. Di samping itu, al$b \bar{a} b$ adalah sisi terdalam akal yang berfungsi untuk menangkap perintah Allah dalam hal-hal yang dapat diindra, seperti halnya sisi luar akal berfungsi untuk menangkap hakekat makhluk, mereka adalah orang-orang yang menyaksikan Rabb melalui ayat-ayat-Nya.

Kaum Ulu al-Albab mempunyai posisi istimewa dan eksklusif di sisi Allah. Hal ini dapat dilihat dalam Q.S. ar-Ra'du : 19. Pada ayat terebut terungkap pernyataan eksklusif Allah bagi kaum Ulu al-Albab, yaitu; 1) Dan tidak dapat mengambil pelajaran dari padanya melainkan orang-orang yang berakal; 2) Hanyalah orang-orang yang berakal yang dapat mengambil pelajaran. Hal ini menunjukkan bahwa selain kaum Ulu al-Albab, orang lain tidak akan mendapat manfaat dan pelajaran. Artinya, selain kaum Ulu al-Albab tidak dapat memahami dengan baik pelajaran yang akan diperoleh dari ayatayat al-Quran. Makna Ulu al-Albab memberikan pancaran kekuatan Illahi yang dikejawantahkan dalam kekuatan intelektual untuk digunakan dalam siru (mengembara) di muka bumi, baik yang tampak maupun yang tidak tampak pancaindra. Ulu al-Albab mempunyai kekuatan (potensi) menganalisis kritis dan men-tadabburi kandungan al-Quran. Ulu al-Albab akan mampu memahami dua dunia, yaitu dunia yang mengandung ayat-ayat dari perbuatan-Nya, sedangkan dunia lainnya mengandung ayat-ayat dari firman-Nya.

Berdasarkan atas ayat-ayat tersebut di atas, para intelektual muslim Indonesia memahami, memberikan definisi dan karakteristik أُولُو الََْلَبَّابِ secara berbeda-beda. Shihab (2000) menyatakan bahwa jika ditinjau secara etimologis, kata "albā $b$ " adalah bentuk plural dari kata $l u b b$, yang berarti saripati sesuatu. Kacang misalnya, memiliki kulit yang menutupi isinya. Isi kacang disebut lubb. Berdasarkan definisi etimologis ini, dapat diambil pengertian bahwa Ulu alAlbab adalah orang yang memiliki akal yang murni, yang tidak diselubungi oleh kulit, yakni kabut ide yang dapat melahirkan kerancuan dalam berfikir. Agak sedikit berbeda, Saefuddin (1987) menyatakan bahwa Ulu al-Albab adalah intelektual muslim atau pemikir yang memiliki ketajaman analisis atas fenomena dan proses alamiah, dan menjadikan kemampuan tersebut untuk membangun dan menciptakan kemaslahatan bagi kehidupan manusia.

Keragaman definisi di atas dapat dirangkum pengertian dan cakupan makna Ulu al-Albab dalam tiga pilar, yakni dzikir, fikir, dan amal shaleh. Secara lebih detail, Ulu al-Albab adalah kemampuan seseorang dalam merenungkan 
secara mendalam fenomena alam dan sosial, yang mendorongnya mengembangkan ilmu pengetahuan, dengan berbasis pada kepasrahan secara total terhadap kebesaran Allah SWT, untuk dijadikan sebagai penopang dalam berkarya positif. Menurut al-Quran, Ulu al-Albab adalah kelompok manusia tertentu yang diberi keistimewaan oleh Allah Swt. Di antara keistimewaannya, mereka diberikan hikmah dan pengetahuan, di samping pengetahuan yang diperoleh mereka secara empiris: "Allah memberikan hikmah kepada siapa yang dikehendakiNya. Barangsiapa yang diberi hikmah, sungguh telah diberi kebajikan yang banyak. Dan tak ada yang dapat mengambil pelajaran kecuali ulul-albab" (QS. al-Baqarah : 269).

Ulu al-Albab adalah orang yang mampu mengharmonisasikan kekuatan intelektual dan spiritualnya. Ciri utama generasi Ulu al-Albab adalah generasi yang senantiasa mengingat Allah dalam setiap keadaan dan kesempatan dan dalam segala aktivitas. Ulu al-Albab adalah orang yang mampu mengharmonisasikan kekuatan intelektual dan spiritualnya dengan mengedepankan $d z i k r$, fikr dan amal shaleh, yang mana ia memiliki ilmu yang luas, pandangan mata yang tajam, otak yang cerdas, hati yang lembut dan semangat serta jiwa pejuangan yang kehadirannya di muka bumi ini sebagai pemimpin dengan menegakkan yang hak dan menjauhkan kebatilan, yang diwujudkan dengan kemampuannya dalam merenungkan secara mendalam fenomena alam dan sosial, yang hal itu mendorongnya mengembangkan ilmu pengetahuan, dengan berbasis pada kepasrahan secara total terhadap kebesaran Allah Swt, untuk dijadikan sebagai penopang dalam berkarya positif (Dakir, 2017).

Sementara itu, manajemen pendidikan Islam adalah manajemen dalam pendidikan Islam, yang mengimplementasikan karakteristik nilai-nilai Islam dalam proses pemanfaatan semua sumber daya yang dimiliki (ummat Islam, lembaga pendidikan atau lainnya), dan dilakukan melalui kerjasama dengan orang lain secara efektif, efisien, dan produktif untuk mencapai kebahagiaan dan kesejahteraan baik di dunia maupun di akhirat (Fauzi, 2018a).

Sementara itu, hasil penelitian Soimatul Ula, berkaitan dengan manajemen pendidikan menurut al-Quran dan Hadis. Dia memaparkan bahwa dalam kaitannya dengan manajemen pendidikan, Islam mensyaratkan adanya sebuah pengelolaan yang di dalamnya mengharuskan keberadaan pemimpin yang berkualitas. Hal ini tertuang dalam Q.S. as-Sajadah : 24. Islam hanya menyediakan bahan baku, sedangkan untuk menjadi sebuah sistem yang operasional, umat Islam diberi kesempatan untuk mengembangkan sistem manajemen pendidikan, dengan menerjemahkan apa yang tersirat dalam ayatayat al-Quran dan Hadis (Sakerani et al., 2019).

Dengan demikian, maka yang disebut dengan manajemen pendidikan Islam adalah proses pemanfaatan semua sumber daya yang dimiliki umat Islam dan lembaga pendidikan atau lainnya, baik perangkat keras maupun lunak. Pemanfaatan tersebut dilakukan melalui kerjasama dengan orang lain secara efektif, efisien dan produktif untuk mencapai kebahagiaan dan kesejahteraan baik di dunia maupun di akhirat (Fadjar, 2005). Pendidikan multikultural perspektif Ulu al-Albab adalah pendidikan multikultural yang diatur dalam 
rangka mengimplementasikan karakteristik nilai-nilai Islam dalam proses pemanfaatan semua sumber daya yang dimiliki (umat Islam, lembaga pendidikan, atau lainnya), dan dilakukan melalui kerjasama dengan orang lain secara efektif, efisien, dan produktif untuk mencapai kebahagiaan di dunia maupun di akhirat.

\section{Bentuk Pendidikan Multikultural dalam Manajemen Prespektif Ulu al-Albab}

Model pendidikan mulikultural yang dilakukan oleh Nabi adalah pendidikan mulikultural yang memberi contoh, bagaimana seharusnya berpikir dan berperilaku. Nah hal inilah yang kemudian secara substansial bisa diterapkan dalam pendidikan mulikultural dan praktek manajerial dalam pendidikan Islam. pendidikan mulikultural mengajarkan bahwa tidak boleh mementingkan dirinya sendiri, menghindari pemenuhan kepentingan pribadi dan golongan tertentu, tetapi mengharuskan punya kemampuan untuk memenuhi dan mewujudkan kepentingan publik, kepentingan masyarakat yang lebih luas (Saleh, 2004).

Pendidikan mulikultural mengajarkan tugas pokok pendidik adalah dengan segenap kesabaran memberikan arah jalannya organisasi melalui keterampilannya dalam mendengarkan, memberikan perhatian, membimbing dan melindungi peserta didik dan orang-orang di lingkungannya (Aprilianto \& Arif, 2019), serta memikul tanggung jawab organisasi kependidikan sehingga menghasilkan kepercayaan dari para peserta didik (Yudiana \& Pardi, 2017). Di sini diperlukan keteladanan (uswah) dalam mengajak peserta didik menuju proses pencapaian insan kamil. Seperti isyarat dalam QS. al-Hujurat : 156, bahwa seorang pendidik dalam dunia pendidikan meski mengajak peserta didik dengan hikmah, kemudian dengan advis dan konseling yang baik, baru kemudian dengan bantahan yang baik. Disini dibutuhkan kehangatan dan keteladanan dari seorang pendidik. Sebagaimana dinyatakan dalam al-Qur'an bahwa Allah menciptakan manusia dalam sebaik-baik bentuk (Q.S. al-Tin : 3), karenanya Allah memerintahkan untuk menyeru manusia kepada jalan Tuhan dengan hikmah dan pelajaran yang baik (Q.S. al-Nahl : 125), dan hendaknya di antara umat manusia yang menyeru kepada kebajikan, menyuruh kepada yang ma'ruf dan mencegah dari yang mungkar (Q.S. Ali Imran : 104), karenanya manusia diperintahkan meluruskan dirinya pada agama Allah yang lurus, yaitu fitrah Allah yang telah ditetapkan Allah kepada manusia (Q.S. al-Rum : 30).

Dalam aspek yang lain, Rasulullah Saw juga memerintahkan kepada kita untuk menyampaikan ajaran kepada orang lain walaupun hanya sedikit (satu ayat), karena semua manusia itu akan celaka kecuali mereka yang memiliki ilmu pengetahuan. Orang yang memiliki pengetahuanpun akan celaka kecuali orang yang mengamalkannya. Orang yang mengamalkanpun akan celaka kecuali mereka yang ikhlas dalam ilmu pengetahuan dan amal yang dilakukannya (al-Hadis). Demikian atas dasar inilah, secara tidak langsung kita diperintahkan untuk menjalankan pendidikan (tarbiyah) dengan sebaik-baiknya agar semua potensi manusia (fitrah) tumbuh dan berkembang dengan baik. 
Perubahan masa yang terus berkembang menjadikan proses pendidikan mulai mencari bentukannya yang terbaru. Selama ini proses pendidikan kita hanya menciptakan dikotomi antara ilmu dengan agama, sehingga terciptalah produk pendidikan yang "timpang". Padahal, pendidikan adalah proses rekayasa yang terencana untuk mengembangkan potensi yang ada dalam diri manusia agar terjadi keseimbangan pada diri manusia. Potensi yang ada dalam diri manusia itu ada 4 (empat) potensi yang harus ditumbuhkembangkan melalui proses pendidikan, yaitu potensi akal, jasmani, ruhani (spiritual) dan kepribadian yang luhur (al-akhlak al-karimah). Keempat potensi ini akan membentuk pribadi yang seimbang dan terarah (Muhaimin, 2003).

Sebagai upaya terencana, pendidikan tinggi niscaya diorientasikan kepada pembentukan "insan kamil harapan". Tidak terkecuali upaya pendidikan yang diselenggarakan Universitas Islam Negeri Maulana Malik Ibrahim Malang. Citra dan jati-diri "insan kamil harapan" yang diupayakan universitas ini adalah insan Ulu al-Albab. Sosok Ulu al-Albab adalah sosok yang mempunyai ketajaman hati dan pandangan yang luas yang tercermin dari berkembangnya empat potensi Ulu al-Albab, yaitu potensi kedalaman spiritual, keagungan akhlak, keluasan ilmu dan kematangan profesional. Semua potensi tersebut akan berhasil dikembangkan dengan baik jika dilakukan rencana yang tepat, yaitu melalui Tarbiyah Ulu al-Albab.

Sejalan dengan prinsip diversifikasi dan kewenangan satuan pendidikan tinggi untuk mengembangkan kerangka dasar dan struktur kurikulumnya, maka selain mengacu pada Standar Nasional Pendidikan, pengembangan kurikulum UIN Maulana Malik Ibrahim Malang juga didasarkan pada filosofi, visi dan misi universitas, yang tercermin dalam kurikulum institusional pada kelompok Matakuliah Pengembangan Kepribadian (MPK) di UIN Maulana Malik Ibrahim Malang. Secara ringkas, keseluruhan muatan kurikulum institusional universitas dimaksud untuk mewujudkan cita-cita menghasilkan sosok pribadi insan Ulu al-Albab. Terdapat beberapa aspek yang telah dan sedang dikembangkan sebagai bentuk pendidikan multikultural di UIN Maulana Malik Ibrahim Malang, yaitu: pertama, aspek pengembangan kelembagaan; kedua, pengembangan sarana prasarana; ketiga, pengembangan akademik; keempat, pengembangan penelitian dan pengabdian masyarakat; kelima, pengembangan kemahasiswaan; keenam pengembangan jaminan mutu; ketuju, pengembangan kerjasama; kedelapan, membangun semangat memberi dan berkorban; dan kesembilan pengembangan karakter akademik dan akhlak mulia.

\section{Praktek Pendidikan Multikultural dalam Manajemen Prespektif $U l u$ al- Albab}

Kunci sukses dari pendidikan mulikultural dalam dunia pendidikan adalah; pertama, kemampuan atau kompetensi seorang pendidik dalam membangun komunitas pendidikanya dengan jalan menguatkan komunikasi dengan peserta didik. Pemimpin harus memiliki pengertian yang baik dan mampu menjalankan roda organisasi kependidikan Islam yang diembannya. Kompetensi disini juga berkaitan dengan kompetensi personal religius seorang 
pendidik, misalkan jujur dan amanah, tidak korup, cerdas, pemaaf, lemahlembut dan hangat terhadap yang dididiknya.

Kedua, visioner, pendidik dalam dunia pendidikan harus bisa mengarahkan organisasi yang didiknya menuju organisasi pendidikan yang baik dan diperhitungkan. Artinya pendidik dalam dunia pendidikan Islam harus bisa menggambarkan tujuan dan capaian yang akan dituju dengan mudah dan simpel, sehingga lingkungan pendidikan Islam yang dididiknya bisa memperoleh gambaran yang jelas, kemudian bersama-sama mencapai visi yang dicanangkan dalam pendidikannya. Ketiga, komunikatif, dalam organisasi kependidikan Islam komunikasi merupakan hal yang amat penting. Password dari komunikasi adalah mendengarkan, pendidik yang baik adalah pendidik yang mendengarkan, karena dengan mendengarkan maka pendidik bisa mengerti keinginan dan kebutuhan yang dididiknya.

Keempat, uswah atau keteladanan, pendidik dalam dunia pendidikan tidak hanya berbicara dan memerintahkan, namun juga memberi contoh (example) bagaimana berperilaku yang baik, tidak hanya teoritik, tetapi juga sekali waktu berdiri di garda depan dalam menyelesaikan problem-problem kependidikan. Kelima, memahami karakter yang dididik, pada dasarnya setiap manusia mempunyai kemampuan, pengalaman, bakat, kecenderungan, minat, sejarah yang berbeda-beda. Pluraitas dasar yang dimiliki manusia inilah yang menjadi dasar, pendidik dalam pendidikan Islam. Artinya mendidik harus sesuai dengan "bahasa kaumnya', keberbedaan peserta didik tidak dipandang sebagai kelemahan tetapi bagaimana perbedaan itu dapat dihimpun menjadi satu kerja raksasa dalam pencapaian tujuan pendidikan Islam. Keenam, adil, keadilan disini dimaknai sebagai keadilan proporsional bukan keadilan distributif. Artinya mendidik harus mampu menimbang mana yang baik dan mana yang buruk dalam penerapan kependidikannya (Fathoni, 2015).

Secara praktis, Universitas Islam Negeri (UIN) Maulana Malik Ibrahim Malang memandang keberhasilan pendidikan mahasiswa berdasarkan standar tertentu. Mereka perlu memiliki identitas dan kepribadian sebagai mahasiswa yang mempunyai: 1) ilmu pengetahuan yang luas; 2) penglihatan yang tajam; 3) otak yang cerdas; 4) hati yang lembut; dan 5) semangat tinggi karena Allah. Hal itu, tentunya juga dibarengi dengan keberadaan dosen dan karyawan yang ada di dalamnya.

Konsep universitas Islam memandang bahwa Islam sebagai ajaran maupun sebagai bidang kajian diyakini-sekurang-kurangnya oleh sebagian besar umat Islam - mencakup berbagai aspek kehidupan, bahkan menjangkau kehidupan dunia dan akhirat sekaligus. Islam mengajarkan setiap manusia mengejar kebahagiaan, kesejahteraan, dan kejayaan duniawi dan ukhrawi. Peran Islam sebagai rahmatan lil'alamin menjadi relevan karena sifat Islam yang serba mencakup (all sufficient), dan dengan sendirinya sebagaimana keyakinan umat sebagai ajaran kehidupan Islam mengajarkan segala yang diperlukan untuk hidup secara baik. Dalam kehidupan umat Islam memperlakukan Islam sebagai sumber inpirasi sekaligus sebagai frame of reference. Ajaran Islam yang tertuang dalam al-Qur'an dan as-Sunnah menempati posisi sentral bagi kehidupan. Dengan demikian Islam bersifat universal, dan inilah sifat 
universalitas Islam, yang serba mencakup, dan berlaku bagi setiap orang, setiap tempat, dan setiap waktu dalam keseluruhan perjalanan hidup manusia.

Sesuai dengan yang telah dipaparkan di atas, bahwa keberhasilan hidup bagi penyandang Ulu al-Albab bukan terletak pada jumlah kekayaan, kekuasaan, sahabat, dan sanjungan yang diperoleh, melainkan keselamatan dan kebahagiaan hidup di dunia dan akhirat. Untuk mewujudkannya, Islam mengarahkan tujuan pokok pendidikannya untuk membentuk manusia religius, yang secara khas lebih dikenal dengan sebutan muttaqin, yaitu orang yang bertakwa kepada Allah Swt.

Paparan tersebut sesuai dengan manajemen yang ada di Universitas Islam Negeri Maulana Malik Ibrahim Malang bahwa manajemen menjalankan tugas-tugasnya dengan berorientasi pada keselamatan hidup di dunia dan akhirat. Prinsip ini mengandung makna strategis bagi pengembangan pendidikan. Keselamatan yang menjadi orientasi mencakup keselamatan yang bersifat jangka pendek (duniawi). Keselamatan juga dapat meliputi kawasan yang luas, yakni untuk semua pihak tanpa terkecuali, dan menyeluruh meliputi aspek lahir dan batin. Orientasi ini juga akan mendorong orientasi kepada kualitas, karena kualitaslah yang dapat diandalkan di masa depan.

Suprayogo menyampaikan pandangannya bahwa berkhidmah di bidang pendidikan pada hakikatnya adalah mengelola kehidupan anak manusia yang akan hidup pada masa depan. Oleh karena itu, harus dilakukan dengan penuh perhitungan dan kesungguhan. Suprayogo berpandangan bahwa mempertahankan model pendidikan yang sesungguhnya sudah usang dan tidak diperlukan lagi bagi kehidupan mendatang adalah sia-sia dan mungkin juga berdosa. Oleh sebab itu, menjadi sebuah keniscayaan jika pengelolaan pendidikan harus selalu dilakukan "reform, change, dan growth" secara terusmenerus. Dunia ini selalu berubah, maka konsekuensinya perubahan dalam pendidikan juga harus selalu dilakukan, baik menyangkut kelembagaannya, kurikulum, kapabilitas tenaga pengajarnya, dan manajerialnya (Fadjar, 2005).

Banyak orang mengatakan bahwa tatkala lembaga perguruan tinggi akan melakukan perubahan, selalu saja menyarankan untuk memperbaiki dulu apa saja yang ada. Tetapi, bagi Suprayogo (2019), perubahan itu sesungguhnya harus dimaknai sekaligus sebagai pendekatan strategis untuk meningkatkan mutu. Idealisme yang besar harus dimaknai sebagai cita-cita yang ditempuh dengan proses pendakian. Cita-cita yang agung dan besar hanya mungkin dilakukan dengan pikiran dan kerja keras, serta perubahan-perubahan besar. Lembaga pendidikan yang ditangani secara asal-asalan, dan tidak bersedia melakukan perubahan, maka dampaknya tidak saja dialami oleh lembaga pendidikan yang bersangkutan, berupa dianggap stagnan, mundur dan ketinggalan zaman, melainkan konsekuensi itu akan dialami pula oleh peserta didiknya.

Awal perjuangan yang baik harus dimulai dari niat yang bersih dan ikhlas, yang kemudian ditopang oleh kerjasama dan kerja keras dari seluruh warga kampus. Perubahan-perubahan besar, apa pun bentuknya, dan apa pun risikonya, harus diciptakan. Tidak ada salahnya jika manusia yang kecil meniru karya Tuhan Yang Maha Agung, Yang Maha Indah, dan yang bermanfaat bagi 
kehidupan. Oleh karena itu, arah pendidikan Ulu al-Albab dirumuskan dalam bentuk perintah sebagai berikut: kunu uli al-ilmi, kunu uli an-nuha, kunu uli alabshar, kunu Ulu al-Albab, wa jahidu fi Allah haqqa jihadih. Betapa pentingnya rumusan tujuan ini bagi pendidikan Ulu al-Albab agar dapat dihayati oleh semua warga kampus Universitas Islam Negeri (UIN) Maulana Malik Ibrahim Malang

Pendidikan Ulu al-Albab berkeyakinan bahwa mengembangkan ilmu pengetahuan bagi komunitas kampus semata-mata dimaksudkan sebagai upaya mendekatkan diri dan memperoleh ridha Allah swt. Akan tetapi, pendidikan Ulu al-Albab juga tidak menafikan arti pentingnya pekerjaan sebagai sumber rizki. Ulu al-Albab berpandangan bahwa jika seseorang telah menguasai ilmu pengetahuan, cerdas, berpandangan luas dan berhati yang lembut serta mau berjuang di jalan Allah, akan mampu melakukan amal shaleh. Konsep amal shaleh diartikan sebagai bekerja secara lurus, tepat, benar atau profesional. Amal shaleh bagi Ulu al-Albab adalah merupakan keharusan bagi komunitas kampus dan alumninya. Sebab, amal shaleh adalah jalan menuju ridha Allah Swt (Azzet, 2011).

Karena itu, tidak sedikit orang yang memahami perguruan tinggi secara sederhana sebatas sebagai tempat bertemunya dosen dan mahasiswa untuk menyelesaikan tugas-tugas pendidikan dan pengajaran. Dosen dianggap sebagai pegawai, berkewajiban memberikan kuliah sebagaimana dijadwalkan. Cara memandang proses belajar di perguruan tinggi secara sederhana ini menjadikan tidak sedikit orang memenuhinya sebatas formal pula. Untuk menjawab pandangan yang hanya sebatas formalitas itu, ada beberapa aspek yang telah dan sedang dikembangkan oleh UIN Maulana Malik Ibrahim Malang, antara lain pengembangan kelembagaan, pengembangan sarana prasarana, pengembangan akademik, pengembangan penelitian dan pengabdian pada masyarakat, pengembangan kemahasiswaan, pengembangan jaminan mutu, pengembangan kerjasama, peningakatan semangat memberi dan berkorban, dan pengembangan karakter akademik dan akhlak mulia.

Adapun strategi untuk mewujudkan perguruan tinggi yang berbasis Islam adalah dengan prinsip-prinsip pengembangan manajemen pendidikan Islam, yaitu seperti apa yang ada pada prinsip-prinsip pengembangan yang ada pada manajemen pendidikan Ulu al-Albab Universitas Islam Negeri Maulana Malik Ibrahim Malang, sebagaimana diungkapkan Suprayogo, yang senada dengan apa yang diungkapkan Muhaimin, yaitu: 1) membangun keyakinan dan komitmen; 2) membangun budaya unggul; 3) mengontrol dan mengevaluasi; 4) memotivasi dan memfasilitasi; 5) meningkatkan kualitas layanan; 6) menciptakan inovasi baru secara terus-menerus; 7) berorientasi kesamaan dan kebersamaan; 8) mengedepankan musyawarah dan saling menasehati; 9) membangun budaya berpuasa; 10) memberdayakan; 11) menumbuhkembangkan gagasan; 12) bertekad menyalurakan aspirasi dan bukan memotong; 13) mengembangkan cita dan tekad bersama; dan 14) memuaskan konsumen. 
Pada konteks di atas, praktek pendidikan multikultural, berkaiatan erat dengan 9 (Sembilan) program pokok atau utama universitas, yaitu: "implementasi integrasi islam dan sains; optimalisasi peran ma'had; peningkatan kompetensi bahasa asing (bilingual); peningkatan kualitas dan kuantitas sumber daya manusia; revitalisasi peran sosial dan keagamaan universitas; optimalisasi manajemen berbasis teknologi informasi; internasionalisasi universitas dan kerjasama internasional (menuju WCU); pengembangan kelembagaan; dan penggalian sumber-sumber pendanaan, yang diarahkan pada pemberdayaan potensi dan kegemaran mahasiswa untuk mencapai target profil lulusannya yang dilandasi kesadaran kolektif dan kewajiban sosial, dengan pendekatan kolegial dan persaudaraan (ukhuwah) antara dosen, karyawan dan mahasiswa, yang dikembangkan melalui proses ta'aruf, tafahum, tadhamun tarahumdan ta'awun serta diperkuat dengan keimanan, tawakkal, sabar, ikhlas, dan beristiqamah, sehingga akan tercetak ulama' intelek profsional dan atau professional intelek ulama.

Untuk mencapai keberhasilan yang maksimal, kegiatan pendidikan dan kemahasiswaan di Universitas Islam Negeri (UIN) Maulana Malik Ibrahim Malang, baik kurikuler, ko-kurikuler, maupun ekstra kurikuler, diarahkan pada pemberdayaan potensi dan kegemaran mahasiswa untuk mencapai target profil lulusan yang memiliki ciri-ciri; 1) kemandirian; 2) siap berkompetisi dengan lulusan Perguruan Tinggi lain; 3) berwawasan akademik global; 4) kemampuan memimpin/sebagai penggerak umat; 5) bertanggung jawab dalam mengembangkan agama Islam di tengah-tengah masyarakat; 6) berjiwa besar, selalu peduli pada orang lain/gemar berkorban untuk kemajuan bersama; dan 7) kemampuan menjadi tauladan bagi masyarakat sekelilingnya. Identitas tersebut tidak hanya menjadi ciri khas Universitas Islam Negeri (UIN) Maulana Malik Ibrahim Malang, melainkan telah menjadi proyeksi umat Islam internasional menuju pencapaian target keilmuan Islam yang global dan dapat mengantarkan manusia pada kesejahteraan, kedamaian, kenyamanan, dan kesenangan yang sebenar-benarnya. Menyadari hal itu semua, dalam suatu pendampingan yang dilandasi kesadaran kolektif dan kewajiban sosial, dengan pendekatan kolegial

Persoalan selanjutnya adalah bagaimana perubahan yang "niscaya" tersebut dapat dikelola secara tepat, sehingga tidak menimbulkan problem baru yang lebih sulit lagi diselesaikan. Di sinilah pentingnya suasana kebersamaan, komitmen untuk maju bersama, serta selalu menghargai berbagai pandangan atau pikiran yang muncul dari mana saja datangnya, sebagai modal utama yang sangat berharga untuk memperjuangkan apa yang dipandang lebih baik di masa yang akan datang. Setelah berusaha keras untuk melakukan yang terbaik, sebagai orang yang beriman, mesti bertawakkal, sabar, ikhlas, dan beristiqamah. 


\section{KESIMPULAN}

Studi ini akhirnya menunjukkan bahwa ada beberapa aspek yang telah dan sedang dikembangkan sebagai bentuk manajemen pengembangan pendidikan multikultural prespektif Ulu al-Albab di Universitas Islam Negeri Maulana Malik Ibrahim Malang, yaitu: aspek pengembangan kelembagaan; pengembangan sarana prasarana; pengembangan akademik; pengembangan penelitian dan pengabdian pada masyarakat; pengembangan kemahasiswaan; pengembangan jaminan mutu; pengembangan kerjasama; membangun semangat memberi dan berkorban; dan pengembangan karakter akademik dan akhlak mulia.

\section{DAFTAR PUSTAKA}

Ahmad, F. (2017). Pendidikan Inklusif Berbasis Kearifan Lokal dalam Praktik Sosial di Pesantren Zainul Hasan Genggong Probolinggo Jawa Timur. Proceedings Ancoms 1St Annual Conference For Muslim Scholars, (110), 715725.

Aprilianto, A., \& Arif, M. (2019). Pendidikan Islam dan Tantangan Multikultural: Tinjauan Filosofis. Nazhruna: Jurnal Pendidikan Islam, 2(2), 279-289. https://doi.org/10.31538/nzh.v2i2.339

Azzet, K. M. (2011). Urgensi Pendidikan Karakter di Indonesia. Yogjakarta: ArRuzz Media.

Baharun, H., \& Awwaliyah, R. (2017). Pendidikan Multikultural dalam Menanggulangi Narasi Islamisme di Indonesia. Jurnal Pendidikan Agama Islam (Journal of Islamic Education Studies), 5(2), 224-243.

Dakir, D. (2017). Pengelolaan Budaya Inklusif Berbasis Nilai Belom Bahadat Pada Huma Betang dan Transformasi Sosial Masyarakat Dayak Kalimantan Tengah. Religió: Jurnal Studi Agama-Agama, 7(1), 28-54. https://doi.org/10.15642/religio.v7i1.707

Dakir, D., \& Anwar, H. (2020). Nilai-Nilai Pendidikan Pesantren sebagai Core Value dalam Menjaga Moderasi Islam di Indonesia. Jurnal Islam Nusantara, 3(2), 495-517. https://doi.org/10.33852/JURNALIN.V3I2.155

Fadjar, M. (2005). Madrasah dan Tantangan Modernitas. Bandung: Mizan.

Farikah. (2019). Developing The Students' Character through Literacy Activities in A Child-Friendly School Model. Dinamika Ilmu, 19(2), 187-196.

Fathoni M. (2015). Pendidikan Islam dan Pendidikan Nasional: Paradigma Baru. Jakarta: Departemen Agama RI: Direktorat Kelembagaan Agama Islam.

Fauzi, A. (2018a). Filsafat Manajemen Pendidikan Islam (Mengurai Benang Kusut Pengelolaan Pendidikan Islam dari Pendekatan Filosofis menuju Praktis). Yogjakarta: Pustaka Pelajar.

Fauzi, A. (2018b). Konstruksi Pendidikan Pesantren; Diskursus terhadap Fundamentalisme dan Liberalisme dalam Islam. Al-Tahrir IAIN Ponorogo, 18(1), 89-114. 
Hidayati, N. (2016). Konsep Pendidikan Islam Berwawasan Multikulturalisme Perspektif HAR. Tilaar. Jurnal Pendidikan Agama Islam, 4(1), 1-24.

Hidayatullah, S. (2016). Developing of Multiculturalism in the Pesantren: Study on KH Abdul Muhaimin and the Pesantren of Nurul Ummahaat. Jurnal Pendidikan Islam, 5(2), 305-324. https://doi.org/10.14421/jpi.2016.52.305324

Kadek Yudiana, I., \& Pardi, W. (2017). Analisis Kerukunan Antar Umat Beragama pada Masyarakat Multikultur di Ujung Timur Pulau Jawa (Studi Kasus di Desa Patoman, Blimbingsari, Banyuwangi, Jawa Timur). Jurnal Ilmu Sosial dan Humaniora, 6(2), 147-158.

Kurniawan, S. (2013). Pendidikan Karakter:Konsepsi dan Implementasinya secara Terpadu di Lingkungan Keluarga, Sekolah, Perguruan Tinggi dan Masyarakat. Yogjakarta: Ar-Ruzz Media.

Maskawaih, I. (1976). Tazib Al Akhlak wa Tazhir Al araq. Kairo: Muassasat Al Khaniji.

Muhadjir, N. (1993). Metodologi Penelitian Kualitatif. Yogjakarta: Take Sarasin.

Muhaimin. (2003). Wacana Pengembangan Pendidikan Islam. Yogyakarta: Pustaka Pelajar.

Nasution. (2014). Metode Research. Jakarta: Bumi Aksara.

Patton, M. (1980). Qualitative Evaluation Methods. Beverly Hills: SAGE Publication.

Riyanta, T. (2016). Mengembangkan Budaya Mutu Sekolah melalui Kepemimpinan Transformasional. Jurnal Manajemen Pendidikan, 12(2), 37-48.

Sagala, S. (2008). Budaya dan Reinventing Organisasi Pendidikan. Bandung: Alfabeta.

Sakerani, Imron, A., Djatmika, E. T., \& Arifin, I. (2019). The Impact of Principal Leadership on Teacher Motivation and Performance: A Mixed Method Approach. International Journal of Innovation, Creativity and Change, 9(10), 312-334.

Saleh, A. R. (2004). Madrasah dan Pendidikan Anak Bangsa. Jakarta: Rajawali Pers.

Setiawan, E. (2017). Pemikiran Abdurrahman Wahid tentang Prinsip Pendidikan Islam Multikultural Berwawasan Keindonesiaan. Jurnal Pendidikan Islam, 2(1), 1-14.

Sidi, I. D. (2001). Menuju Masyarakat Belajar: Menggagas Paradigma Baru Pendidikan. Jakarta: Logos Wacana Ilmu.

Suyatno. (2015). Sekolah Dasar Islam Terpadu dalam Konsepsi Kelas Menengah Muslim Indonesia. Analisa Journal of Social Science and Religion, 22(1), 121133.

Yusuf, I. (2014). Ismail al-Faruqi's Contribution to the Academic Study of Religion. Islamic Studies, 53(1), 99-115. 